\title{
EFFECTS OF QUERCETIN ON CYTOKINES AND PULMONARY CAPILLARY CELLS IN PULMONARY ARTERIAL HYPERTENSION RATS
}

\author{
WEIQUN ZHANG ${ }^{1}$, YAN LI $^{1}$, YONG LUO ${ }^{1}$, DELI YE ${ }^{2 *}$ \\ ${ }^{1}$ Department of Clinical Laboratory, The First People's Hospital of Lin'an District, Lin'an, Hangzhou 310000, Zhejiang, China \\ ${ }^{2}$ Department of Clinical Laboratory, Zhejiang Provincial People's Hospital, Hangzhou 310014, Zhejiang, China \\ *corresponding author: dr_yedeli2003@163.com
}

Manuscript received: January 2020

\begin{abstract}
This study aimed to investigate the effects of quercetin in the treatment of pulmonary arterial hypertension (PAH) in a murine model. Thirty-six adult male rats were randomly divided into three groups: the control group (saline), monocrotaline (MCT) induced PAH group (MCT group) and quercetin treatment group (prevention group). After modelling, the animals from prevention group received $100 \mathrm{mg} / \mathrm{kg}$ bw/day quercetin by gavage and the gavage for 20 days, while the animals from the other two groups received the same amount of $0.9 \%$ sodium chloride saline solution. The mean pulmonary artery pressure, right ventricular index and relative expression levels of HIF-1 (hypoxia-inducible factor 1), ET-1(vascular endothelin-1), TGF- $\beta 1$ (transforming growth factor- $\beta 1$ ), VEGF (vascular endothelial growth factor), IL-1 (interleukin-1), IL-6 (interleukin-6) and TNF- $\alpha$ (tumour necrosis factor $\alpha$ ) in lung tissues significantly increased in MCT group compared with the control group, 21 days after modelling. The levels of HGF (hepatocyte growth factor) and NAC (N-acetyl-L-cysteine) significantly increased compared with the control group. The treatment with quercetin significantly decreased the level of mean PAH, right ventricular index and relative expression levels of HIF-1, ET-1, TGF- $\beta 1$, VEGF, IL-1, IL- 6 and TNF- $\alpha$ in lung tissues compared with MCT group and significantly decreased the levels of HGF and NAC. In vitro experiment with PCEC (pulmonary capillary endothelial cells) from the three groups showed that in the MCT group the cell proliferation was significantly decreased and the apoptosis was significantly increased compared with the control group, while the quercetin treatment inhibited the MCT-induced cell apoptosis and promoted cell proliferation. In conclusion, quercetin can alleviate $\mathrm{PAH}$ by regulating the inflammatory cytokines, promoting cell proliferation and inhibition of cell apoptosis.
\end{abstract}

\section{Rezumat}

Acest studiu a avut ca scop investigarea efectelor quercetinei în tratamentul hipertensiunii arteriale pulmonare (HAP) într-un model murin. Treizeci și șase de șobolani masculi au fost împărțiți în mod aleatoriu în trei grupuri: grupul martor (soluție salină), grupul MCT (cu HAP indusă de monocrotalină) și grupul de tratament cu quercetină. Animalele din grupul quercetinei au primit $100 \mathrm{mg} / \mathrm{kgc} /$ zi quercetină prin gavaj timp de 20 de zile, în timp ce animalele din celelalte două grupuri au primit aceeași cantitate de soluție salină._Presiunea arterială pulmonară medie, indicele de hipertrofie ventriculară și valorile expresiei HIF-1, ET-1, TGF- $\beta 1$, VEGF, IL-1, IL-6 și TNF- $\alpha$ în țesuturile pulmonare au crescut semnificativ în grupul MCT comparativ cu grupul martor, după 21 de zile. Valorile HGF și NAC au crescut semnificativ în comparație cu grupul control. Tratamentul cu quercetină a redus semnificativ nivelul HAP mediu, indicele hiperventricular şi valorile expresiei HIF-1, ET-1, TGF- $\beta 1$, VEGF, IL-1, IL-6 și TNF- $\alpha$ în țesuturile pulmonare, comparativ cu Grupul MCT. Valorile HGF și NAC au scăzut semnificativ. Experimentul in vitro cu PCEC (celule endoteliale pulmonare capilare) din cele trei grupuri a arătat că în grupul MCT proliferarea celulară a fost semnificativ scăzută și apoptoza a crescut semnificativ în comparație cu grupul martor, în timp ce tratamentul cu quercetină a inhibat apoptoza celulară indusă de MCT şi a favorizat proliferarea celulară. În concluzie, quercetina poate ameliora HAP prin reglarea citokinelor inflamatorii, promovând proliferarea celulară și inhibarea apoptozei.

Keywords: quercetin, pulmonary arterial hypertension, pulmonary capillary endothelial cells, cytokines

\section{Introduction}

Pulmonary arterial hypertension (PAH) is a common and life-threatening disease. It is characterized by continuous and significant increase of pulmonary artery pressure, which eventually leads to right ventricular failure and death $[1,2]$. The pathological mechanism of PAH development is complex and multifaceted, and its main feature is the continuous increase of distal pulmonary artery resistance. The common factors of increased resistance include pulmonary vasoconstriction, in situ thrombosis and pulmonary vascular reconstruction. Pulmonary vasoconstriction can lead to alveolar hypoxia and imbalance of vasoactive mediators such as chlorine monoxide and serotonin secretion. Long term contraction can promote in situ thrombosis and lead to vascular reconstruction. PAH is a key pathological link of many common diseases, such as chronic obstructive 
pulmonary disease, chronic thromboembolism, connective tissue disease, and also an independent risk factor for increasing incidence rate and decreasing survival. It seriously affects the quality of life and prognosis of patients [3]. In recent years, although the research on PAH gene and molecular biology has made great progress, the clinical efficacy has been raised, but unfortunately did not change the high incidence rate and mortality $[4,5]$. It is of great significance to explore the pathological mechanism of $\mathrm{PAH}$ for finding effective therapeutic targets.

Quercetin is a natural dietary flavonoid, spread in nature with low toxicity [6]. In the past 20 years, it has attracted researchers' attention due to its wide range of pharmacological effects, including antioxidant, anti-inflammatory and anti-cancer [7-10]. For a variety of 33 tumour cell lines, quercetin can inhibit the proliferation of various types of tumour cells, induce their apoptosis, promote their cell cycle arrest, reduce tumour cell migration, and play an anti-tumour role [11]. Besides, some recent studies have shown that quercetin can effectively inhibit coronary and pulmonary vasoconstriction and reduce blood pressure [12]. It was also found that in the PAH rat model induced by MCT, the formation of PAH can be significantly reversed by quercetin [13], however, the key molecular regulatory mechanism is still unclear.

In this research, we investigated if quercetin can effectively reverse PAH using a murine model, the cytokines' expression and the stimulation of pulmonary capillary endothelial cells (PCEC) proliferation.

\section{Materials and Methods}

PAH animal model and experimental groups
Thirty-six adult male Sprague Dawley, weighing 250 $325 \mathrm{~g}$, were provided by Nanjing Junke Bioengineering Co., Ltd., China, and the center provided breeding and observation sites. The PAH model used was obtained by administration of a single dose of $50 \mathrm{mg} / \mathrm{kg}$ bw monocrotaline (Sigma-Aldrich, USA). The rats were randomly divided into three groups: the normal control group (control group), the monocrotaline (MCT)-induced PAH group (MCT group) and quercetin treatment group (prevention group), 12 animals per group. Rats in the MCT group and prevention group were injected with $50 \mathrm{mg} / \mathrm{kg}$ bw MCT and then observed for 21 days. Rats in the control group were injected with $0.9 \%$ sodium chloride solution and then observed for 21 days. After modelling, the prevention group received $100 \mathrm{mg} / \mathrm{kg}$ bw/day quercetin (GlpBio, China) by gavage for 20 days, while the animals from MCT and control groups received the same amount of $0.9 \%$ sodium chloride by gavage for 20 days. The administration and treatment of rats during this study were in accordance with the regulations for the protection of experimental animals and the protocol was approved by the Ethical Committee of The First People's Hospital of Lin'an District, China.

Physiological index detection

The pulmonary artery pressure (PAP) was measured in the three groups of rats after 20 days of administration according to Firrest et al. method [14]. After PAP was measured, the animals were killed by cervical dislocation and the hearts were collected. The right and left ventricles were separated and weighed. The weight ratio was used as the right ventricular hypertrophy index (RVHI), was calculated according to the following formula in order to assess the degree of right ventricular hypertrophy:

$$
\text { weight ratio }=\frac{\text { weight of right ventricles }}{\text { Weight of left ventricle and interventricular septum }}
$$

PCEC (pulmonary capillary endothelial cells) collection and primary culture

The fresh lung tissue was collected from the rats from each group, digested in $0.25 \%$ pancreatin (ChemeGen, USA) at $37^{\circ} \mathrm{C}$ for 5 minutes, and then the tissue was carefully cut in $2-3 \mathrm{~mm}$ segments from the edge of the lung leaf and cut it into $1 \mathrm{~mm}^{3}$ small pieces. Then the tissue was dissolved in $20 \mathrm{~mL}$ endothelial cell culture medium (ECM1001, ScienCell, USA), and $6 \mathrm{~mL} 0.25 \%$ collagenase IV (Roche, Shanghai, China) was added for digestion in $37^{\circ} \mathrm{C}$ incubator for $15 \mathrm{~min}$. Then $6 \mathrm{~mL}$ of $1.0 \%$ neutral protease solution (Roche, Shanghai, China) was added and the digestion was continued for $15 \mathrm{~min}$ at $37^{\circ} \mathrm{C}$ in an incubator for 15 min. The complete digestion of cells was observed under the microscope. When the digestion was stopped, another $10 \mathrm{~mL}$ ECM medium was added and centrifuged at $4000 \mathrm{rpm}$ for 2 - 5 minutes. After centrifugation, the supernatant was discarded and $3 \mathrm{~mL}$ serum (Thermo Fisher, USA) was added to induce cell aggregation and centrifuged at $100 \mathrm{rpm}$ for 6 minutes. The supernatant was discarded and the precipitation was collected and mixed with $20 \mathrm{~mL}$ ECM and inoculate into culture bottle. After incubation at $37^{\circ} \mathrm{C}$ in a $5 \% \mathrm{CO}_{2}$ incubator for 2 - 4 hours, the cells and fragments that were not attached to the wall were removed, and the new ECM was added to continue the cell culture.

MTT (3-(4,5-dimethylthiazol-2-yl)-2,5-diphenyltetrazolium bromide)) assay

The PCECs were collected, adjusted to the cell concentration of $3 \times 10^{4}$ cells $/ \mathrm{mL}$, inoculated in a 96-well plate at a concentration of $100 \mu \mathrm{L} /$ well and cultured at $37^{\circ} \mathrm{C}$ in a $5 \% \mathrm{CO}_{2}$ incubator for 24 hours. Then the original culture medium was discard and $100 \mu \mathrm{L}$ ECM was added in each well. Each group of cells were worked in triplicate. After 24 hours, 48 hours and 72 hours of continuous culture the original culture medium was discarded and $100 \mu \mathrm{L}$ ECM containing $5 \mathrm{mg} / \mathrm{mL}$ MTT (Sigma-Aldrich, USA) was added into each well. After 4 hours of continuous 
FARMACIA, 2021, Vol. 69, 1

culture, the liquid from each well was discarded and $100 \mu \mathrm{L}$ DMSO (Aladdin, Shanghai, China) was

added and samples were assessed at $750 \mathrm{~nm}$.

$$
\text { cell inhibition rate }(\%)=\frac{1-\text { experimental group }}{\text { control group }}
$$

\section{Hoechst staining}

The PCECs were collected, adjusted to the cell concentration of $1 \times 10^{5}$ cells $/ \mathrm{mL}$, inoculated in a 6 well plate at a concentration of $2 \mathrm{~mL} /$ well, covered with a glass, and cultured at $37^{\circ} \mathrm{C}$ in a $5 \% \mathrm{CO}_{2}$ incubator for 24 hours. Then the medium from the plate was discarded and a new ECM medium was added and further cultured at $37^{\circ} \mathrm{C}$ in a $5 \% \mathrm{CO}_{2}$ incubator for 48 hours. Afterwards culture, the medium from each well was discarded and $0.5 \mathrm{~mL}$ fixing solution (4\% paraformaldehyde, Sigma-Aldrich, USA) was added and kept for $10-20 \mathrm{~min}$. The wells were washed with PBS and $1 \mathrm{~mL}$ Hoechst33342 staining solution was added to each well. The cell morphology was observed and photographed under an inverted fluorescence microscope (IXplore SpinSR Super Resolution Microscope System, Plympus, Beijing, China).

Western blot assay and cytokine detection

The lung tissues were collected, rinsed with PBS, added with the corresponding volume of lysate was added, and left on ice for 5 minutes. The lysates were mixed and the samples were centrifuged at $12000 \mathrm{rpm}, 4^{\circ} \mathrm{C}$, for 10 minutes. The supernatant obtained represent the total protein extract of the cell. The protein concentration was determined by bicinchoninic acid assay (BCA Protein Assay Kit, ab102536, Abcam, China). The protein concentration in each group was equalized by adding $1 \times$ SDS gel buffer and then the protein samples were diluted with $5 \times$ loading buffer (ThermoFisher, USA) and PBS, boiled for $5 \mathrm{~min}$ and denatured. The protein liquid after denaturation was added to $12 \%$ SDS-PAGE gel (SDS-PAGE Gel kit, Elabscience, Wuhan, China) and underwent $80 \mathrm{~V}$ constant pressure electrophoresis for 60 - $120 \mathrm{~min}$. The SDS-PAGE glue was placed on the nitrocellulose membrane to carry out constant current transfer. 3\% BSA (bovine serum albumin, ThermoFisher, USA) was used in the final step. The nitrocellulose membrane was washed with PBS and monoclonal anti-HIF-1, anti-ET-1, anti-TGF- $\beta 1$, anti-
VEGF, anti-IL-1, anti-IL-6, anti-TNF- $\alpha$, anti-HGF and anti-NAC antibody (Abcam, China), was added at 1:500 concentration. The membrane was incubated at room temperature for 45 minutes. Then the nitrocellulose membrane was washed with PBS buffer, and the incubation with the second antibody (Antimouse IgG for IP (HRP), ab131368, Abcam, China) was started. The second antibody labelled with horseradish peroxidase was added at 1:1000 and incubated at room temperature for 30 minutes. Then, the PBS buffer was used to wash the nitrocellulose membrane and the ECL chemiluminescence agent (Proandybio, Xi'an, China) was used for chemiluminescence. Kodak $\mathrm{X}$ (Coolfilm, China) was used to expose the nitrocellulose membrane for about three minutes. The $\mathrm{X}$-ray film was scanned and the gray analysis of the strip was processed by Gel-Pro Analyzer software (Software, Germany). The gray value of each band was measured in three independent replicates.

Statistical analysis

SPSS 21.0 software (IBM, USA) was employed. One way ANOVA was used for comparing the groups, Lenvene method was used for homogeneity of variance, Student-Newman-Keuls (SNK) method was used for comparison between two groups of data on the basis of homogeneity of variance. A value of $p<0.05$ indicates significant differences.

\section{Results and Discussion}

Pulmonary artery pressure and right ventricular hypertrophy index

The PAP and RVHI significantly increased in the MCT group compared with the control group (Table I). The treatment with quercetin significantly decreased the level of PAP and RVHI compare with the MCT group, but without reaching the levels of the control group (Table I).

Table I

Comparison of PAP and RVHI in rats of each group

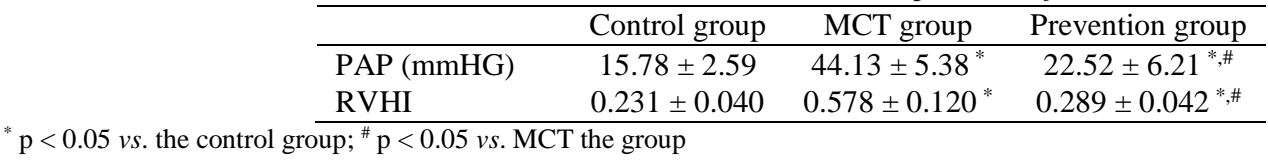

The relative expression levels of cytokine

According to the results of Western blot assay, the relative expression levels of HIF-1, ET-1, TGF- $\beta 1$, VEGF, IL-1, IL-6 and TNF- $\alpha$ in lung tissues were significantly increased in the MCT group compared with the control group. The treatment with quercetin significantly increased the HIF-1, ET-1, TGF- $\beta 1$, VEGF, IL-1, IL-6 and TNF- $\alpha$ levels compared with MCT group
(Figure 1). The relative level of HGF and NAC were significantly decreased in the MCT group compared with the control group. The quercetin treatment reverses the MCT effect on HGF and NAC (Figure 1).

Proliferation and apoptosis of PCEC

PCEC in three groups of rats were cultured in the primary culture, and the proliferation and apoptosis of cells in different groups were compared. The MTT 
and Hoechst staining assay showed that compared with the control group, the proliferation ability of
PCEC in the MCT group was significantly decreased and apoptosis was significantly increased (Figure 2).

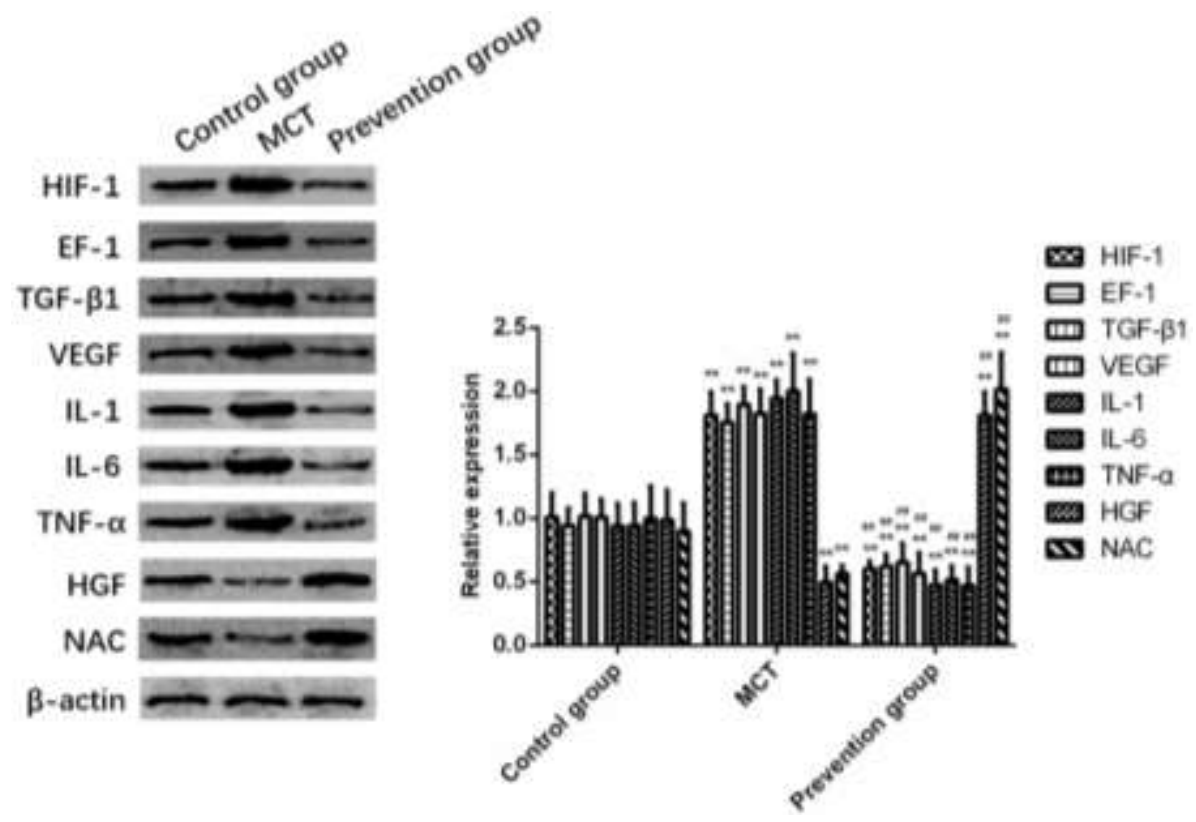

Figure 1.

Western blot analysis of the expression of cytokines in lung rat tissues in each group ${ }^{* *} \mathrm{p}<0.01$ vs. the control group; ${ }^{\#} \mathrm{p}<0.01$ vs. the MCT group

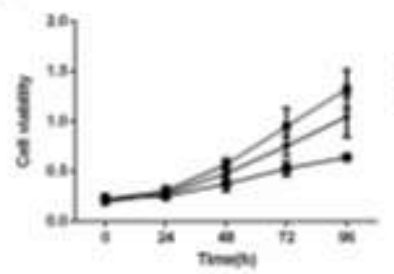

8

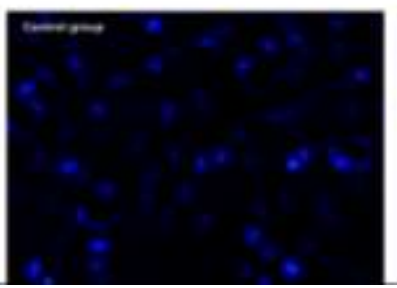

\section{- cores}

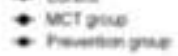

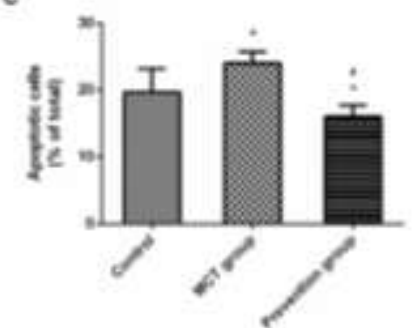

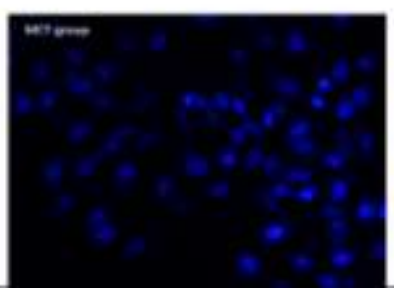

Figure 2.

Detection of cell proliferation and apoptosis. A: Detection of cell proliferation using MTT assay. B: Quantitative results of Hoechst staining. C: Qualitative result of Hoechst staining ${ }^{*} \mathrm{p}<0.05$ vs. the control group; ${ }^{\#} \mathrm{p}<0.05$ vs. the MCT group

As a part of the human normal diet, quercetin has a long history. With the development of research on the biological and pharmacological activities of quercetin, more and more studies have shown that quercetin is beneficial to human health, including anti-cancer, anti-allergy, anti-inflammatory, anti-atherosclerosis and other effects [15-17]. Quercetin is a flavonoid with many bioactivities, high medicinal value and is widely distributed in vegetal products. In recent years, researchers focused on its properties and confirmed that it has a variety of biological effects.
Recently, it has been reported that quercetin can significantly alleviate pulmonary hypertension induced by MCT [18], but its potential molecular mechanism is still poorly understood. In this study, we found that quercetin can reverse pulmonary hypertension induced by MCT, which is consistent with previous results. The main pathological changes observed in PAH are pulmonary vasoconstriction, in situ thrombosis and pulmonary vascular remodelling [19]. The results of this study showed that the injury of endothelial cells is the starting point in $\mathrm{PAH}$, and the enhancement of 
pulmonary vasoconstriction and the reconstruction of pulmonary vascular structure can be considered as the main characteristics of vascular changes after the injury of endothelial cells. The dysfunction of endothelial cells leads to the abnormal proliferation of intima and smooth muscle cells, the decrease of apoptosis, and finally the reconstruction of pulmonary vessels. Pulmonary vascular endothelial cells are considered to be the early mechanism of idiopathic $\mathrm{PAH}$, which is accompanied by endothelial cell proliferation and apoptosis resistance.

The relative expression levels of HIF-1, ET-1, TGF$\beta 1$, VEGF, IL-1, IL-6 and TNF- $\alpha$ in lung tissues were significantly higher in the MCT group than in the control group, however, after the administration of quercetin the upregulation of inflammatory cytokines is reversed. The levels of HGF and NAC were decreased in the MCT group and significantly increased in the quercetin prevention group. Transcription factor NAC is an anti-apoptotic factor that modulates the expression of TNF- $\alpha$ and ICAM-1 (intercellular adhesion molecule 1). HGF regulates cell growth, cell motility, and morphogenesis by activating a tyrosine kinase signalling cascade after binding to the proto-oncogenic c-Met receptor, and acts as a multi-functional cytokine on cells of mainly epithelial origin [20]. Its ability to stimulate mitogenesis, cell motility and matrix invasion gives it a central role in angiogenesis, tumorigenesis, and tissue regeneration. HGF is a potent mitogen for mature parenchymal hepatocyte cells, it seems to be a hepatotropic factor, and acts as a growth factor for a broad spectrum of tissues and cell types [20].

Previous studies have been shown that quercetin has directly reverses vasoconstriction caused by various endogenous factors (norepinephrine, ET-1, TXA2), protein kinase $(\mathrm{PKC})$ activator and depolarizing factor (such as $\mathrm{KCl}$ ) [21]. The molecular mechanism of this effect is not completely clear. It may be related to the multiple effects of PKC and myosin light chain kinase. The effect of PKC on resistance vessels is higher than on volume vessels. Quercetin at low concentration can inhibit the release of ET-1 and the transcription of its precursor by inhibiting tyrosine kinase in bovine aortic endothelial cells. Quercetin can inhibit the migration and proliferation of endothelial cells, mainly by blocking DNA synthesis to make it stagnate in cell cycle G0/G1, and can reduce the level of vascular endothelial growth factor by expressing cyclin inhibitory kinase p27 [21]. According to Hsieh et al. quercetin can inhibit the proliferation of pulmonary artery endothelial cells and induce apoptosis [22]. It acts by inhibition of cell proliferation through blocking the S-phase and G2-phase of cell cycle and upregulating p53 and p21 expression and the apoptotic Bax gen that induce apoptosis [22]. Tolllike receptor (TLR) plays an important role in the process of inflammation [23]. As an important transmembrane protein in the immune system, TLR can recognize various pathogenic related molecules and is an important barrier for the body to resist infectious diseases [24]. Among them, TLR4 is the earliest TLR that can mediate the body's response to pathogens. When the body is stimulated by relevant pathogenic molecules, TLR4 can induce the release of inflammatory cytokines such as IL-1 $\beta$, IL-6, TNF by activating nuclear factor- $\kappa \mathrm{B}(\mathrm{NF}-\kappa \mathrm{B})$ [25-27].

Our in vitro experiments showed that compared with the control group, the proliferation ability of PCEC in MCT group was significantly decreased and apoptosis was significantly increased, while quercetin could inhibit the apoptosis of PCEC and promote cell proliferation. The results suggest that quercetin may also inhibit the expression of related cytokines and regulate cells through TLR4 mediated inflammatory signalling pathway.

\section{Conclusions}

Our study showed that quercetin had a therapeutic effect on PAH. It is suggested that the therapeutic effect of quercetin on PAH may be related to the regulation of cytokines, the promotion of cell proliferation and the inhibition of apoptosis. In addition, quercetin may also play a role in the treatment of PAH by inhibiting platelet aggregation and improving the function of vascular endothelial cells.

This study suggests that quercetin has a therapeutic effect on MCT induced PAH in rats and further clinical studies should investigate these findings also in humans in order to provide a new therapeutic alternative for $\mathrm{PAH}$.

\section{Conflict of interest}

The authors declare no conflict of interest.

\section{References}

1. Yan L, Chen X, Talati M, Nunley BW, Gladson S, Blackwell T, Cogan J, Austin E, Wheeler F, Loyd J, West J, Hamid R, Bone marrow-derived cells contribute to the pathogenesis of pulmonary arterial hypertension. Am J Respir Crit Care Med., 2016; 193(8): 898-909.

2. Guo Y, An B, Lang Z, Zhou F, Zhang X, Wang F, Effects of curcumin on inhibiting the proliferation of pulmonary artery smooth muscle cells and relieving pulmonary arterial hypertension. Farmacia, 2019; 67(2): 307-312.

3. Robinson JC, Graham BB, Rouault TC, Tuder RM, The crossroads of iron with hypoxia and cellular metabolism. Implications in the pathobiology of pulmonary hypertension. Am J Respir Cell Mol Biol., 2014; 51(6):721-729.

4. Zhao M, Austin ED, Hemnes AR, Loyd JE, Zhao $\mathrm{Z}$, An evidence-based knowledgebase of pulmonary arterial hypertension to identify genes and pathways relevant to pathogenesis. Mol Biosyst., 2014; 10(4): 732-740.

5. Taichman DB, Ornelas J, Chung L, Klinger JR, Lewis S, Mandel J, Palevsky HI, Rich S, Sood N, Rosenzweig 
EB, Trow TK, Yung R, Elliott CG, Badesch DB, Pharmacologic therapy for pulmonary arterial hypertension in adults: CHEST guideline and expert panel report. Chest, 2014; 146(2): 449-475.

6. Rauf A, Imran M, Khan IA, Ur-Rehman M, Gilani SA, Mehmood Z, Mubarak MS, Anticancer potential of quercetin: A comprehensive review. Phytother Res., 2018; 32(11): 2109-2130.

7. Sharifi-Rad M, Anil Kumar NV, Zucca P, Varoni EM, Dini L, Panzarini E, Rajkovic J, Tsouh Fokou PV, Azzini E, Peluso I, Prakash Mishra A, Nigam M, El Rayess Y, Beyrouthy ME, Polito L, Iriti M, Martins N, Martorell M, Docea AO, Setzer WN, Calina D, Cho WC, Sharifi-Rad J, Lifestyle, oxidative stress, and antioxidants: back and forth in the pathophysiology of chronic diseases. Front Physiol., 2020; 11: 694: 1-21.

8. Abarikwu SO, Simple G, Onuoha SC, Mokwenye I, Ayogu JF, Evaluation of the protective effects of quercetin and gallic acid against oxidative toxicity in rat's kidney and HEK-293 cells. Toxicol Rep., 2020; 7: 955-962.

9. Hassan AMS, Abo El-Ela FI, Abdel-Aziz AM, Investigating the potential protective effects of natural product quercetin against imidacloprid-induced biochemical toxicity and DNA damage in adults rats. Toxicol Rep., 2019; 6: 727-735.

10. Sharifi-Rad M, Lankatillake C, Dias DA, Docea AO, Mahomoodally MF, Lobine D, Chazot PL, Kurt B, Tumer TB, Moreira AC, Sharopov F, Martorell M, Martins N, Cho WC, Calina D, Sharifi-Rad J, Impact of natural compounds on neurodegenerative disorders: from preclinical to pharmacotherapeutics. J Clin Med., 2020; 9(4): 1061: 1-19.

11. Fernández-Palanca P, Fondevila F, Méndez-Blanco C, Tuñón MJ, González-Gallego J, Mauriz JL, Antitumor effects of quercetin in hepatocarcinoma in vitro and in vivo models: a systematic review. Nutrients, 2019; 11(12): 2875: 1-31.

12. Jing Z, Wang Z, Li X, Li X, Cao T, Bi Y, Zhou J, Chen X, Yu D, Zhu L, Li S, Protective effect of quercetin on posttraumatic cardiac injury. Sci Rep., 2016; 6: 30812: 1-10.

13. Gao H, Chen C, Huang S, Li B, Quercetin attenuates the progression of monocrotaline-induced pulmonary hypertension in rats. J Biomed Res., 2012; 26(2): 98-102.

14. Forrest JB, Todd MH, Cragg DJ, A simple method of percutaneous cannulation of the pulmonary artery in small mammals. Can Anaesth Soc J., 1979; 26(1): 58-60.

15. Senthilkumar K, Arunkumar R, Elumalai P, Sharmila G, Gunadharini DN, Banudevi S, Krishnamoorthy G, Benson CS, Arunakaran J, Quercetin inhibits invasion, migration and signalling molecules involved in cell survival and proliferation of prostate cancer cell line (PC-3). Cell Biochem Funct., 2011; 29(2): 87-95.
16. Pradhan SJ, Mishra R, Sharma P, Kundu GC, Quercetin and sulforaphane in combination suppress the progression of melanoma through the down-regulation of matrix metalloproteinase-9. Exp Ther Med., 2010; 1(6): 915920.

17. Farzaei MH, Rahimi R, Abdollahi M, The role of dietary polyphenols in the management of inflammatory bowel disease. Curr Pharm Biotechnol., 2015; 16(3): 196-210.

18. Morales-Cano D, Menendez C, Moreno E, MoralSanz J, Barreira B, Galindo P, Pandolfi R, Jimenez R, Moreno L, Cogolludo A, Duarte J, Perez-Vizcaino F, The flavonoid quercetin reverses pulmonary hypertension in rats. PLoS One, 2014; 9(12):e114492: 1-20.

19. Thenappan T, Ormiston ML, Ryan JJ, Archer SL, Pulmonary arterial hypertension: pathogenesis and clinical management. BMJ, 2018; 360: j5492, doi: https://doi.org/10.1136/bmj.j5492.

20. Nakamura T, Mizuno S, The discovery of hepatocyte growth factor (HGF) and its significance for cell biology, life sciences and clinical medicine. Proc Jpn Acad Ser B Phys Biol Sci., 2010; 86(6): 588-610.

21. Pérez-Vizcaíno F, Ibarra M, Cogolludo AL, Duarte J, Zaragozá-Arnáez F, Moreno L, López-López G, Tamargo J, Endothelium-independent vasodilator effects of the flavonoid quercetin and its methylated metabolites in rat conductance and resistance arteries. J Pharmacol Exp Ther., 2002; 302(1): 66-72.

22. Hsieh TC, Juan G, Darzynkiewicz Z, Wu JM, Resveratrol increases nitric oxide synthase, induces accumulation of p53 and p21(WAF1/CIP1), and suppresses cultured bovine pulmonary artery endothelial cell proliferation by perturbing progression through S and G2. Cancer Res., 1999; 59(11): 2596-2601.

23. Zălar DM, Pop C, Buzdugan E, Todea D, Mogoşan CI, The atherosclerosis-inflammation relationship - a pathophysiological approach. Farmacia, 2019; 67(6): 941-947.

24. Langlet C, Springael C, Johnson J, Thomas S, Flamand V, Leitges M, Goldman M, Aksoy E, Willems F, PKC-alpha controls MYD88-dependent TLR/IL-1R signaling and cytokine production in mouse and human dendritic cells. Eur J Immunol., 2010; 40(2): 505-515.

25. Zhang T, Wang J, Wang S, Ma C, Timosaponin BII inhibits lipopolysaccharide-induced acute lung

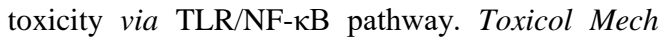
Methods, 2015; 25(9): 665-671.

26. Liu L, Li YH, Niu YB, Sun Y, Guo ZJ, Li Q, Li C, Feng J, Cao SS, Mei QB, An apple oligogalactan prevents against inflammation and carcinogenesis by targeting LPS/TLR4/NF- $\kappa$ B pathway in a mouse model of colitis-associated colon cancer. Carcinogenesis, 2010; 31(10): 1822-1832.

27. Cui L, Feng L, Zhang ZH, Jia XB, The antiinflammation effect of baicalin on experimental colitis through inhibiting TLR4/NF- $\kappa$ B pathway activation. Int Immunopharmacol., 2014; 23(1): 294-303. 